\title{
SPATIO-TEMPORAL STUDY AND POPULATION STRUCTURE OF DAPTONEMA OXYCERCA (NEMATODA: XYALIDAE) IN COROA GRANDE, RIO DE JANEIRO, BRAZIL*
}

\author{
Tatiana F. Maria ${ }^{\text {I, }}{ }^{\text {**}}$; Neyvan R. R. da Silva ${ }^{3,4}$; Adriane P. Wandeness ${ }^{4}$ and André M. Esteves ${ }^{4}$ \\ ${ }^{1}$ Universidade Federal do Rio de Janeiro, Instituto de Biologia \\ Departamento de Zoologia \\ (Av. Brigadeiro Trompowsky, S/N, Ilha do Fundão 21941-590, Rio de Janeiro, RJ, Brasil) \\ ${ }^{2}$ Ghent University - Biology Department, Marine Biology Section \\ (Krijgslaan 281 S8, B-9000 Ghent, Belgium) \\ **tatiana_fabricio@yahoo.com.br \\ ${ }^{3}$ Centro Federal de Educação Tecnológica do Rio Grande do Norte (CEFET) \\ (Unidade Descentralizada da Zona Norte Rua Brusque S/N, Potengi, Natal/RN, Brasil) \\ ${ }^{4}$ Universidade Federal de Pernambuco - Departamento de Zoologia \\ (Av. Prof. Moraes Rêgo, S/N Centro de Ciências Biológicas, Recife/PE, Brasil)
}

\begin{abstract}
Daptonema oxycerca was originally described from the North Sea and, up to now, nothing is known of this species in tropical regions. The spatio-temporal distribution and the population structure of this species was studied during one-year period (from May 1998 through April 1999) in Coroa Grande, Rio de Janeiro, Brazil. For sampling, two fixed, parallel transects were established perpendicularly to the shoreline, and at each transect, four, equally spaced levels were marked to represent the upper and the low intertidal zones. The lowest temperatures occurred in the end of the austral winter and first month of the spring and the highest temperatures occurred in the austral summer. The density of $D$. oxycerca varied during the year, with a peak in August. This tendency was observed for males, ovigerous females, and non-ovigerous females. The species density was negative correlated with temperature. The sex ratio was not statistically significant. $D$. oxycerca was most abundant at the upper intertidal level in both transects. This work provides the first record of $D$. oxycerca in Brazil, and confirms the influence of temperature in regulating its population density.
\end{abstract}

\section{RESUMO}

Daptonema oxycerca foi descrita originalmente para o Mar do Norte, mas até o momento nada se conhece sobre essa espécie em regiões tropicais. A distribuição espaço-temporal e a estrutura populacional de $D$. oxycerca foram estudadas durante o período de um ano (de Maio 1998 a Abril 1999) em Coroa Grande, Rio de Janeiro, Brasil. Para a amostragem, dois transectos fixos e perpendiculares à linha d'água foram estabelecidos, e, em cada transecto, quatro níveis foram marcados para representar as zonas superior e inferior do médiolitoral. As menores temperaturas foram observadas no final do inverno e início da primavera e as maiores temperaturas no verão. A densidade de $D$. oxycerca variou durante o ano, com um pico em agosto. Essa tendência foi observada para os machos, as fêmeas grávidas e as fêmeas não-grávidas. A densidade da espécie correlacionou-se negativamente com a temperatura. A variação da razão sexual não foi significativa. D. oxycerca foi mais abundante no nível superior do médiolitoral em ambos os transectos. Esse trabalho representa o primeiro registro de $D$. oxycerca no Brasil, assim como, confirma a influência da temperatura na regulação de sua densidade populacional.

Descriptors: Daptonema, Marine nematodes, Population structure, Sepetiba Bay.

Descritores: Daptonema, Nematódeos marinhos, Estrutura populacional, Baía de Sepetiba. 


\section{INTRODUCTION}

Nematodes are the most abundant metazoan group in the entire biosphere in relation to the number of individuals (VIGLIERCHO, 1991); it is estimated that $80 \%$ to $90 \%$ of all metazoans are nematodes (BONGERS, 1988; JAIRAJPURI; AHMAD, 1992). They occur in diverse habitats, even some seemingly uninhabited, such as glaciers and the deep sea (POIMAN, 1983). The free-living nematodes have been well studied in the benthic habitat, particularly in temperate zones; however, in tropical areas these animals have received little attention, probably because of their small size and the time required to identify them (ALONGI, 1990). In Brazil, taxonomic work on free-living nematodes began in the mid-20th century (GERLACH, 1954, 1956a, 1956b, 1957a, 1957b). Studies then ceased until the end of the century, when a new group of investigators began work, principally relating the occurrence of nematodes to ecological aspects (MEDEIROS, 1998; NETTO; GALLUCCI, 2003; ESTEVES et al., 2003, 2004; GENEVOIS et al., 2004; DA ROCHA et al., 2006).

Marine nematodes have been used as bioindicators in environmental-impact studies of pollution in sandy beaches, estuaries and mangroves. Because of their high abundance in the meiofauna and their small size, nematodes respond rapidly to changes in biotic and abiotic environmental factors (SCHRATZBERGER et al., 2000; GHEISKIERE et al., 2004; 2005). Moreover, they have a wide adaptive spectrum, high diversity, short life cycle, continuous reproduction, and a benthic lifestyle (HEIP et al., 1985).
Daptonema oxycerca De Man, 1888 was originally described from the North Sea. Later records broadened its known distribution in the northern hemisphere (HOPPER, 1969). A study of the spatiotemporal structure of a nematode community in a temperate region also showed the presence of this species and its preference for the upper intertidal zone (RZENIK-ORIGNAC et al., 2003). The influence of salinity on $D$. oxycerca is known from ex-situ studies (FOSTER, 1998). However, up to now, nothing is known of this species in tropical regions. According to previous data, this species is one of the most abundant species of the tidal flat of Sepetiba Bay (ESTEVES, 2004). Thus the aim of this paper was to describe the spatio-temporal distribution and population structure of Daptonema oxycerca in Coroa Grande, state of Rio de Janeiro, Brazil, during the course of one year, in order to assess whether any environmental factors (chlorophyll $a$, granulometry, organic matter, salinity, and temperature) influenced its distribution. This is also the first record of this species from the Brazilian coast.

\section{Material and Methods}

Study Area

Coroa Grande is a tidal flat located in

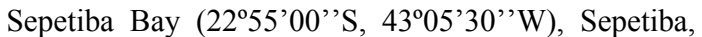
Rio de Janeiro State, Brazil (Fig. 1). The bay is 305 $\mathrm{km}^{2}$ in area and from 2 to $12 \mathrm{~m}$ deep. Human occupation and industrial activity, discharging domestic and industrial waste, have affected the bay (MOSALIN et al., 2004).

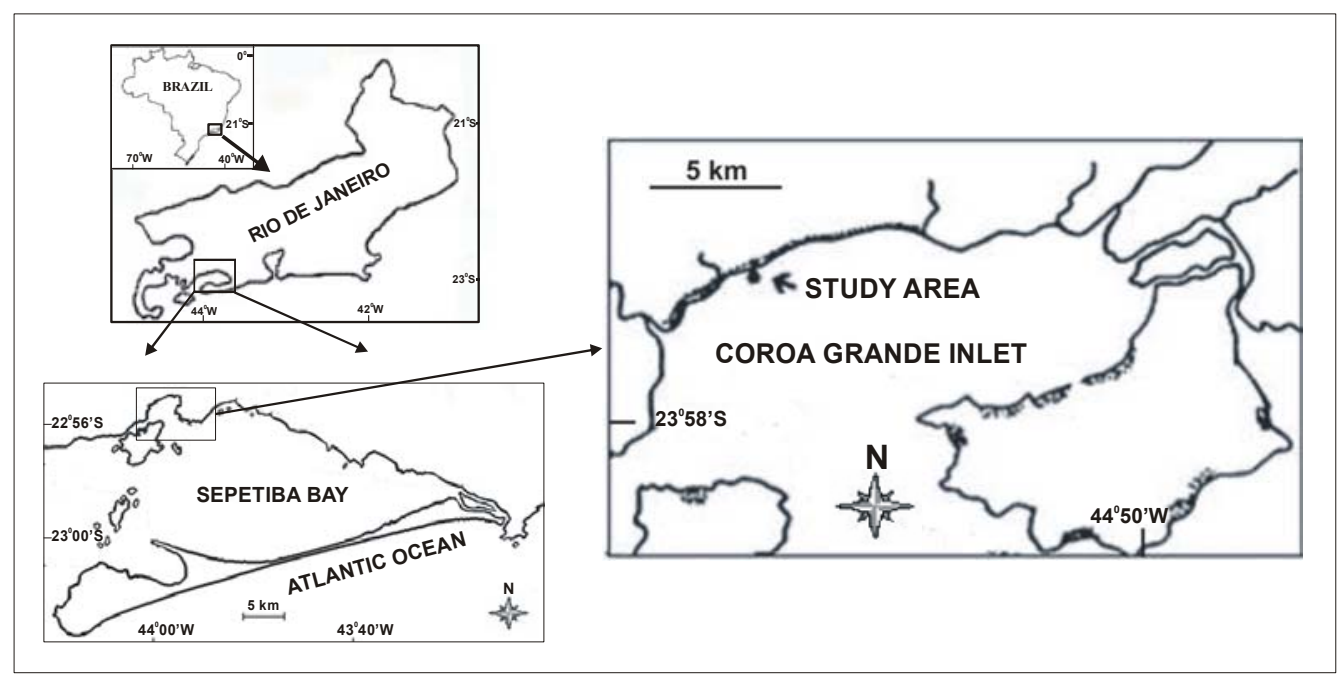

Fig. 1. Study area inside of Sepetiba Bay, Brazil sampled from May 1998 to April 1999. 
Sampling

Two fixed, parallel transects (Profiles A and B) were established perpendicularly to the shoreline, $200 \mathrm{~m}$ apart. On each transect, four and equally spaced levels ( $60 \mathrm{~m}$ apart) were marked and designated as 20 , 80,140 , and 200. Levels 20 and 80 represented the upper intertidal zone (UIZ), whereas levels 140 and 200 represented the low intertidal zone (LIZ) (Fig. 2). At each level, three replicates were taken for each parameter, using cores of $1 \mathrm{~cm}^{2}$ and $5 \mathrm{~cm}$ deep (systematically located $3 \mathrm{~m}$ apart) for meiofauna, and cores of $10 \mathrm{~cm}^{2}$ for organic matter, granulometry, and chlorophyll $a$. The sediment samples to analyze meiofauna were fixed in situ with $4 \%$ formalin. Temperature was measured with a soil thermometer and salinity was measured using a salinometer. The two sites were sampled monthly from May 1998 to April 1999.

\section{Laboratory Analysis}

Grain size was determined by dry-sieving, using a set of sieves with mesh sizes decreasing from $1 \mathrm{~mm}$ to $62.5 \mu \mathrm{m}$. The grains were desegregated by drying in an oven at $100^{\circ} \mathrm{C}$ for $24 \mathrm{~h}$ and the samples were then passed through the sieves and shaken by an automatic shaker for 10 min (BUCHANAN, 1984). For each sample, the mean grain size and degree of sorting were calculated (FOLK; WARD, 1957).
In the laboratory, the nematodes were extracted using the sugar-flotation method (ESTEVES; DA SILVA, 1998). The upper size limit was defined as a mesh sieve of $500 \mu \mathrm{m}$, and the lower limit as a mesh size of $50 \mu \mathrm{m}$. The meiofauna retained on the $50 \mu \mathrm{m}$ mesh was counted and identified to the level of major taxon by means of a stereomicroscope. The nematodes were picked out and transferred to a solution of 5 parts glycerin, 5 parts ethanol, and 90 parts distilled water. They were mounted on glycerin slides following the procedures described by Platt and Warwick (1983).

The nematodes were identified to genus level using the pictorial keys of Platt and Warwick (1983) and Warwick et al. (1998). Specimens of Daptonema were measured for species identification. They were also identified as males, ovigerous females, non-ovigerous females, or juveniles. The mean density was expressed as number of individuals per $10 \mathrm{~cm}^{2}$.

Pearson's correlation analysis was carried out (ZAR, 1996) to test the relationship between Daptonema oxycerca, temperature, and salinity in the case of temporal distribution; and between the species density, organic matter, and chlorophyll $a$ in the case of spatial distribution. Differences in the population densities along both profiles were tested using an analysis of variance (ANOVA). The chi-square test was applied to test the significance of the sex ratio considering $\alpha \leq 0.05$.

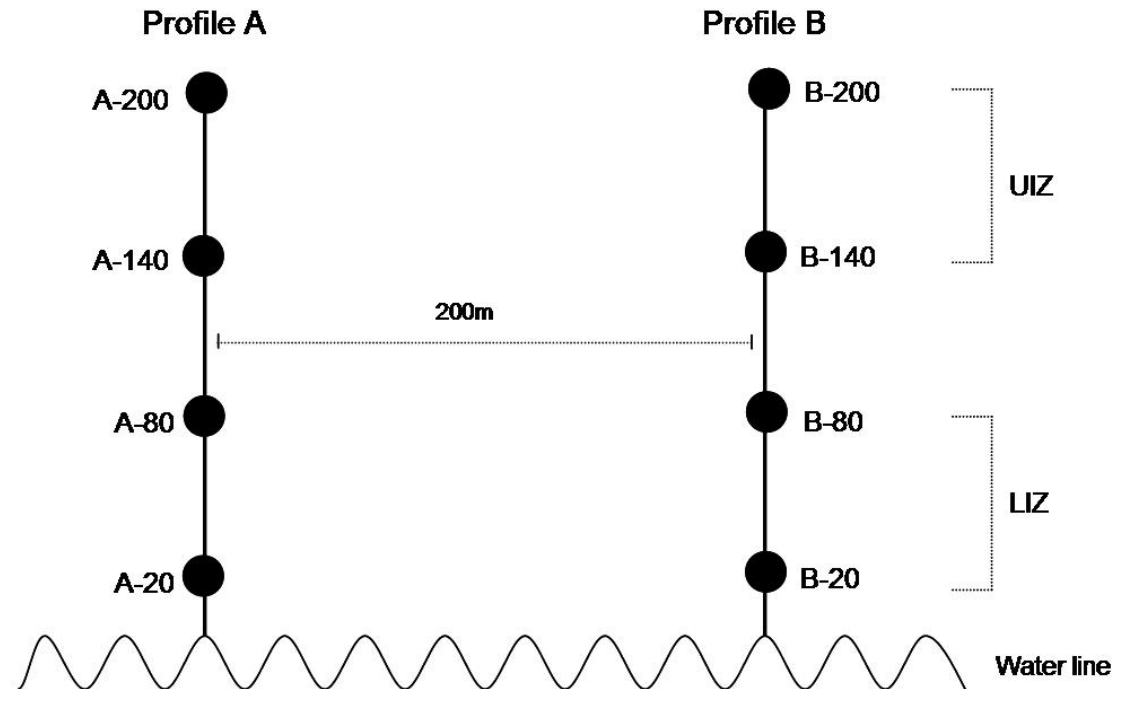

Fig. 2. Sampling design with two profiles (A and B) along tidal flat. UIZ: upper intertidal zone, LIZ: low intertidal zone. 


\section{Results}

Environmental Data

Temperature and salinity varied during the months of the study. The lowest temperatures occurred in July, August and September $\left(21,22\right.$ and $23^{\circ} \mathrm{C}$, respectively), and the highest temperatures in
December, January and February $\left(30.5,31\right.$ and $30.5^{\circ} \mathrm{C}$, respectively). The lowest salinity was equal to 9 and occurred in October, whereas the highest was recorded in May and equal to 31 (Fig. 3).

Organic matter was the highest in the LIZ, varying between 4 and $6 \%$; and the lowest in the UIZ, being approximately $2 \%$, independent of the profile (Fig. 4 A).

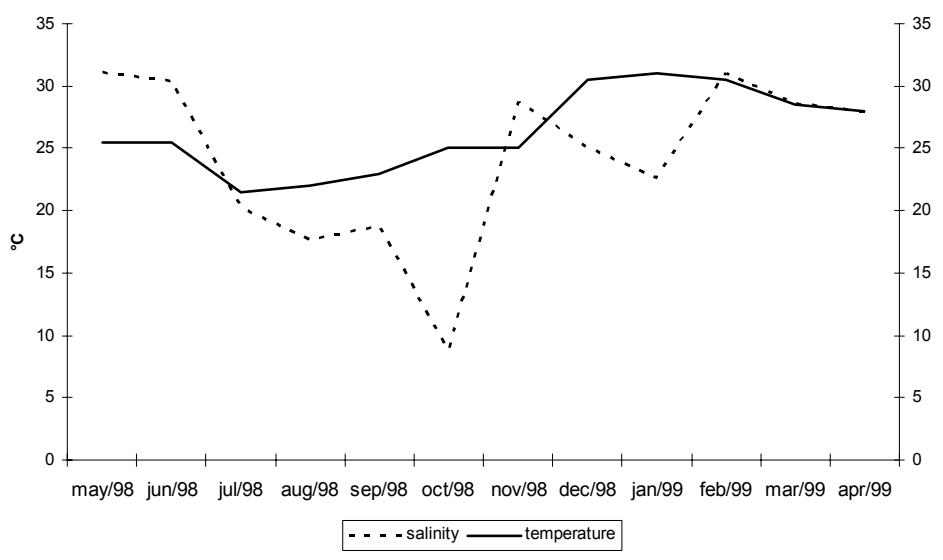

Fig. 3. Temporal variation of temperature and salinity.

$\mathbf{A}$

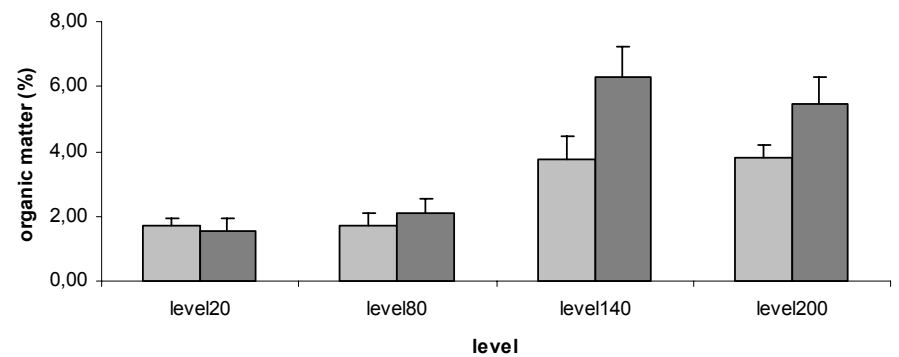

B

$\square$ Profile A $\square$ Profile B

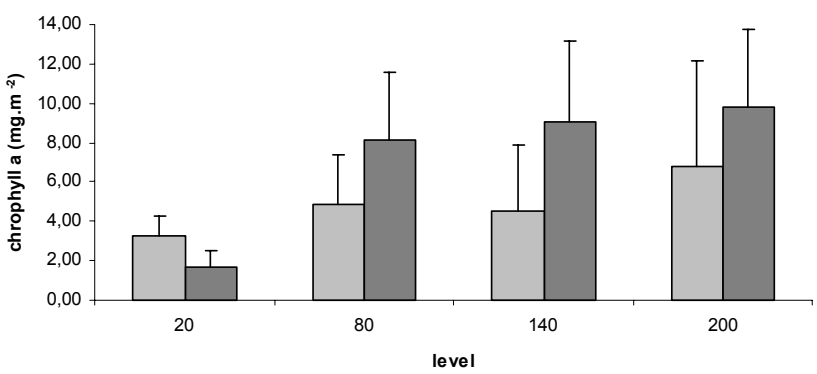

$\square$ Profile A $\square$ Profile B

Fig. 4. Annual average of abiotic parameters at each profile A- organic matter; B- chlorophyll $a$. 
Chlorophyll $a$ varied along both profiles: it was the highest at the 80, 140 and 200-levels in Profile B $\quad\left(8.1 \quad \mathrm{mg} . \mathrm{m}^{-2} ; \quad 9.0 \quad \mathrm{mg} \cdot \mathrm{m}^{-2}\right.$ and $9.8 \quad \mathrm{mg} \cdot \mathrm{m}^{-2}$ respectively), and the lowest at the 20-level in Profile A $\left(1.6 \mathrm{mg} \cdot \mathrm{m}^{-2}\right)$ (Fig. $\left.4 \mathrm{~B}\right)$.

Grain size ranged from coarse to fine sand. The sediments from all levels were poorly sorted, except from the 80-level in Profile A (Table 1).

\section{Population Structure}

The density of the population of $D$. oxycerca varied during the year. There was a peak in August of 2,560 ind.10 $\mathrm{cm}^{-2}$ (Fig. 5). The same tendency was observed for the categories: males, ovigerous females, and non-ovigerous females. Females comprised the largest part of the population (59\%), and juveniles were the smallest part $(8 \%)$ during the whole year (Fig. 6). Species density was correlated negatively with temperature $(\mathrm{r}=-0.77 ; \mathrm{p}<0.05)$ and was not correlated with salinity $(r=-0.62 ; p>0.05)$ (Fig. 7). The sex ratio ranged from $0.33(\mathrm{Dec} / 98)$ to $2.00(\mathrm{Jan} / 99)$ and was not statistically significant $\left(\chi^{2}=3.83 ; \mathrm{p}>\right.$ $0.05)$. D. oxycerca was most abundant at the 80 -level in both profiles, and the difference between the levels was statistically significant $(\mathrm{F}=10.66, \mathrm{p}<0.00001)$ (Fig. 8).

Density values in the different levels showed a negative correlation with organic matter and a positive one with chlorophyll $a$. However, almost all the results were not statistically significant, except for the level 140 of profile A (Table 2).

Table 1. Results of the granulometry of profile A and B.

\begin{tabular}{|c|c|c|c|c|c|}
\hline \multirow[b]{2}{*}{ Level } & & \multicolumn{2}{|c|}{ Profile A } & \multicolumn{2}{|c|}{ Profile B } \\
\hline & & Sediment Content & Sorted level & Sediment Content & Sorted level \\
\hline & 20 & Coarse Sand & Badly Sorted & Coarse Sand & Badly Sorted \\
\hline & 80 & Coarse Sand & Moderately Sorted & Medium Sand & Badly Sorted \\
\hline & 140 & Medium Sand & Badly Sorted & Fine Sand & Badly Sorted \\
\hline & 200 & Medium Sand & Badly Sorted & Fine Sand & Badly Sorted \\
\hline
\end{tabular}

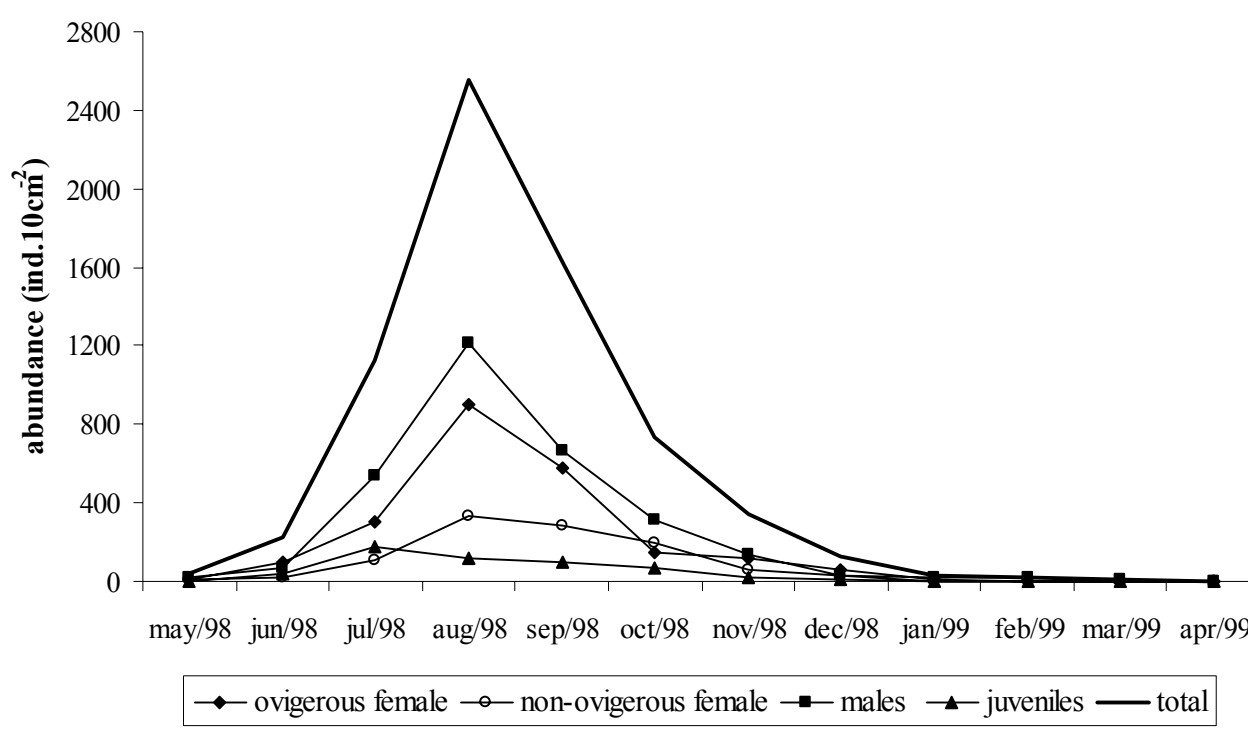

Fig. 5. Abundance of Daptonema oxycerca during the period of study. 


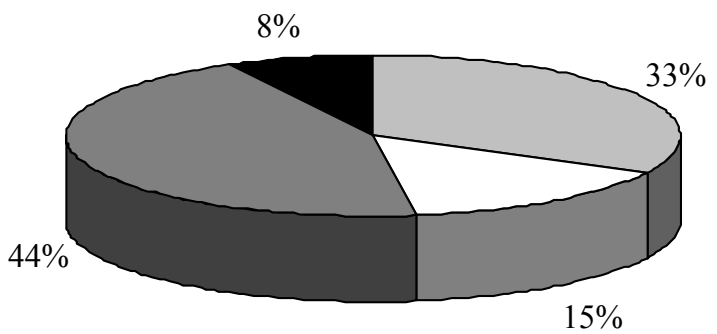

\section{$\square$ ovigerous female $\square$ non-ovigerous female $\square$ male $\mathbf{\square}$ juveniles}

Fig. 6. Percentage of Daptonema oxycerca population categories for the entire year studied $\left(\mathrm{n}=6.850\right.$ ind $\left..10 \mathrm{~cm}^{-2}\right)$.

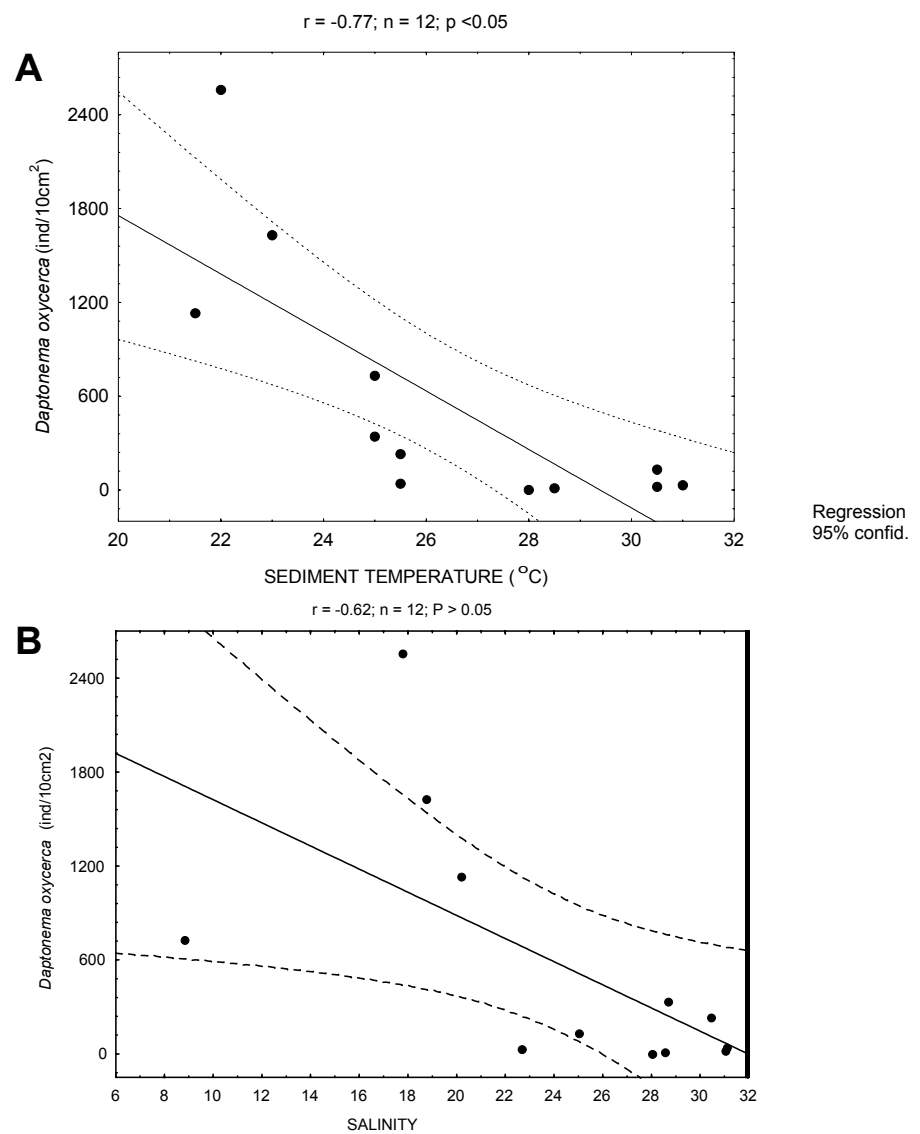

Fig. 7. Pearson's correlation A - between density of Daptonema oxycerca and temperature; B - between density of Daptonema oxycerca and salinity. 


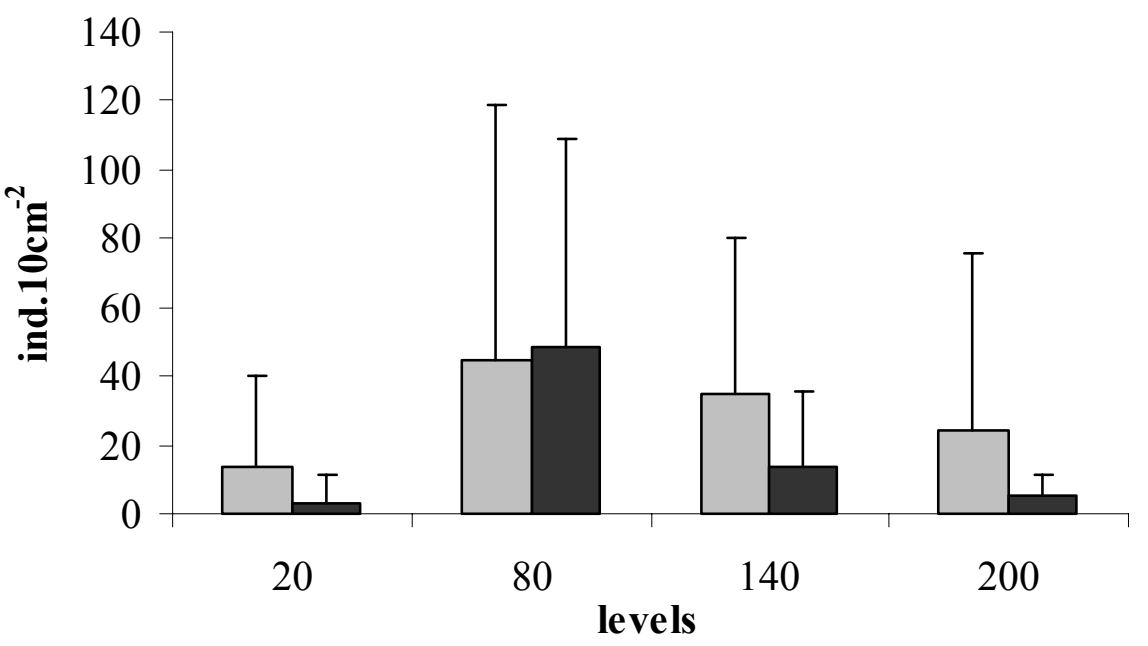

\section{$\square$ Profile A $\square$ Profile B}

Fig. 8. Spatial distribution of Daptonema oxycerca.

Table 2. Results of the correlation between the density of Daptonema oxycerca, organic matter and chlorophyll $a(\mathrm{P}<0,05)$.

\begin{tabular}{ccccc}
\hline \hline \multicolumn{3}{c}{ Profile A } & & Profile B \\
\hline Level & Organic Matter & Chlorophyll $a$ & Organic Matter & Chlorophyll $a$ \\
20 & -0.14 & 0.59 & -0.58 & 0.35 \\
80 & -0.32 & 0.17 & -0.52 & 0.40 \\
140 & -0.36 & $0.71^{*}$ & -0.20 & 0.12 \\
200 & -0.29 & 0.56 & -0.12 & 0.10 \\
\end{tabular}

* Significant correlation

\section{Discussion}

Despite of Daptonema oxycerca being one of the most abundant nematode species in the marine sediments of the tidal flat at Coroa Grande, this is the first report of this species in Brazil. Its known distribution up to now was limited to the North of Europe (North, Baltic, and Mediterranean Seas and Nova Scotia) (HOPPER, 1969). The lack of a previous record in Brazil was probably due to the poor stage of identification of the collected material along the Brazilian coast, mostly reaching only the genus level. The knowledge on the local nematode species has improved very recently with the increase of taxonomists in the group (ESTEVES et al., 2003; 2004; VENEKEY et al., 2005; CASTRO et al., 2006, BOTELHO et al., 2007).

Results on the spatial distribution of $D$. oxycerca indicated a preference of the species for the 80-level. However, none of the factors analyzed seems to be responsible for this distribution since the tests of correlation performed with organic matter and chlorophyll $a$ gave no statistically significant results. The granulometry may not explain this distribution either, because it was not much different at the 80level respecting the other levels. A highest abundance of $D$. oxycerca in the UIZ was also recorded by Foster (1998), who estimated 200,500 indiv. $\mathrm{m}^{-2}$ in the higher 
levels. In relation to its temporal distribution the highest density was found in August, when the temperature of the sediment was lower. These results are partially in agreement with previously published information, where an evaluation of the nematode community structure in Brouage mudflat (MarennesÓleron Bay) showed that none of the physical and biological parameters analyzed, such as chlorophyll $a$, organic matter as well as heavy metals, was directly responsible for the spatial variation in the community, even though the temporal variation showed the dominance of this species when the temperature rose (RZEZNIK-ORIGNAC, 2003).

Explanations for decrease in density of the nematode community during autumn and summer are frequently related to decrease in oxygen availability, in food supply, and predation by the macrofauna (COULL et al., 1995; FELLER, 1984; PLATT; WARWICK, 1980). In the Coroa Grande system, food limitation may not be the determinant factor because of the continuous, year-round input of domestic sewage (AMADO-FILHO et al., 1999). This sewage input indirectly promotes the increase of bacteria and protozoa in the sediment, which are some of the main food resource for deposit-feeders, following the buccal classification of Wieser (1953). Nevertheless, some considerations should be done. For instance, the food quality may not be the same throughout the year, although this parameter was not analyzed in the present study. Since an increase in temperature increases the decomposition rate and consequently raises the quantity of bacteria, $D$. oxycerca would be expected to reach its highest density during the warm months. However, the inverse was observed. Another important factor for nematodes is the strict association between the buccal cavity and the food resource (WIESER, 1953). This association, however, was strongly criticized by Moens and Vincx (1997) and the doubt remains till nowadays. Is it true that a nematode with a large and unarmed buccal cavity only feeds on bacteria and protozoa? As discussed by these authors, the feeding strategy differs for each species, and diatoms are also an important food for deposit feeders. Diatom frustules were found in the intestines of Daptonema setosum (MOENS; VINCX, 1997) and in Theristus sp. (BOUCHER, 1974), another member of the Xyalidae. Consequently, it seems not to be a food limitation, as proposed by Wieser (1953). Considering all these aspects, food may not be a determinant factor in the distribution of Daptonema oxycerca.

Comparing the results of this study with the previous studies by Esteves et al. $(2003,2004)$ in the same tidal flat, Daptonema oxycerca behaved similarly to Comesoma arenae, preferring the colder months. Comesoma arenae had its highest densities during July and August, austral winter, whereas $D$. oxycerca showed a peak in August and occurred only from June to November. Hence, nematode species may respond differently to the seasonal variations, which demonstrates the importance of studies at the species level.

Although the correlation between density and salinity was not statistically significant, the lower abundance and even absence of $D$. oxycerca in the warm months may be directly associated with the increase in salinity. As shown by Guarini et al. (1997), the temperature and salinity of intertidal sediments are extreme during the summer because when temperature increases, the salinity also rises. Foster (1998), analyzing the stress tolerance of many nematode species in experimental conditions, concluded that $D$. oxycerca cannot tolerate long periods in hypertonic conditions, even though the specimens used in his study were collected in the lower intertidal zone.

The presence of ovigerous females and juveniles only from June to November may indicate that $D$. oxycerca does not reproduce continuously during the year, as observed for the other two species studied at the same site (ESTEVES et al., 2003, 2004). However, the mesh size of $50 \mu \mathrm{m}$ used for the lower limit is not able to collect all juveniles, and so it may have resulted in an underestimation of the number of individuals of that stage. However, the most important factor limiting any speculation about the life cycle of this species is the long interval between samples, i.e., one month. In most cases, the life cycle of nematodes may be completed, from adult to adult, in a period of two to four weeks, as shown by Tietjen and Lee (1972). Moens and Vincx (2000), studying Diplolaimelloides meyli, the most closely related species to $D$. oxycerca that had its life cycle described, found that it was completed in 2 days at $25^{\circ} \mathrm{C}$ and 7 days at $9^{\circ} \mathrm{C}$.

In conclusion, the present results indicate that, at Coroa Grande, Daptonema oxycerca seems to prefer the upper intertidal level, being more acclimated to survive in an environment with low temperature and salinity. However, further studies are needed on the subject. Knowledge on the ecology of nematode species would be improved as experimental and field studies accumulate.

\section{ACKNOWLEDGEMENTS}

The authors are grateful to the staff of the Meiofauna Laboratory of the Universidade Federal de Pernambuco for their help in the species identification; to Prof. Dr. Guilherme Muricy of the Museu Nacional, Universidade Federal do Rio de Janeiro, for his critical reading of an earlier draft of this manuscript.

\section{REFERENCES}

ALONGI, D. M. Community of free-living nematodes in some tropical mangroves and sandflat habitats. Bul. mar. Sci., v. 46, n. 2, p. 358-373, 1990. 
AMADO-FILHO, G. M.; REZENDE, C.E. ; LACERDA L.D. Poluição da baía de Sepetiba já ameaça outras áreas. Ciência Hoje, v. 25, p. 46-48, 1999.

BONGERS, T. 1988. De nematoden van Nederland. Utrecht, Netherlands: K. Nederlandse Natuurhist. Vereninging, 1899.

BOUCHER, G. Premières données écologisques sur les Nématodes libres marins d'úne station vase cotière de Banyuls. Vie Milieu, Serie B - Oceanographie, v. 23, p. 69-100, 1974.

BOTELHO, A. P.; SILVA, M. C.; ESTEVES, A. M. ; FONSECA-GENEVOIS, V. Four new species of Sabatieria Rouville, 1903 Nematoda, Comesomatidae) from the Continental Slope of Atlantic Southeast Zootaxa, v. 1402, p. 39-57, 2007

BUCHANAN, J. B. Sediment analysis. In: HOLME, N.A.; MCINTYRE, A. D. (Ed). Methods for the study of marine benthos. Boston: Blackwell Scientific Publishers, 1984. p. 41-65.

CASTRO, F. J. V.; BEZERRA, T. N. C.; SILVA, M. C.; FONSÊCA-GENEVOIS, V. Spirinia elongata, sp.nv (Nematoda, Desmodoridae) from Pina Basin Pernambuco, Brazil. Zootaxa, v. 1121, p. 53-68, 2006.

COULL, B. C.; GREENWOOD, J. G.; FIELDER, D. R. COULL, B. A. Subtropical Australian juvenile fishes eat meiofauna: experiments with winter whiting English Channel: a simulation analysis. Mar. Ecol. Progr. Ser. v. 125, p. 13-19, 1995.

DA ROCHA, C. M. C.; VENEKEY, V.; BEZERRA, T. N. C.; SOUZA, J. R. B. Phytal marine nematode assemblages and their relation with the macrophytes structural complexity in a Brazilian tropical rocky beach. Hydrobiologia, v. 553, p. 219-230, 2006.

ESTEVES, A. M. Free-living marine nematodes from Coroa Grande tidal flat (Sepetiba Bay, Rio de Janeiro, Brazil) Biociências, v. 12, n. 2, p. 185-186. 2004.

ESTEVES, A. M. ; DA SILVA, V.M.A.P. The behavior of sugar flotation technique in meiofauna extraction from different sand types. Tropic. Ecol., v. 39, n. 2, p. 283284, 1998

ESTEVES, A. M.; MARIA, T. F.; WANDENESS, A. P. Population structure of Oncholaimus cobbi (Kreis, 1932) in a tropical tidal flat. J. mar. biol. Ass. U.K., v. 83, p. 903-904, 2003.

ESTEVES, A. M.; MARIA, T. F.; WANDENESS, A. P. Population structure of Comesoma arenae Gerlach (Nematoda: Comesomatidae) in a brazilian tropical tidalflat, Rio de Janeiro, Brazil. R. bras. Zool., v. 21 , n. 4, p. 775-777, 2004.

FELLER, R. J. Serological tracts of meiofaunal food webs. Hydrobiologia, v. 118, p. 119-125, 1984.

FOLK, R. C. ; WARD, W.C. Brazos River Bay: A study in the significance of grain parameters. J. sed. Petrology, v. 27, n. 1 , p. $3-27,1957$

FOSTER, S. J. Osmotic stress tolerance and osmorregulation of intertidal and subtidal nematodes. J. expl mar. Biol. Ecol., v. 224,p. 109-125, 1998.

GENEVOIS, V.; SANTOS, G. A. P.; CASTRO, F. J. V.; ALMEIDA, A. P. T. C. M.; COUTINHO, R. Biodiversity of marine nematodes from an atypical tropical coastal area affected by upwelling (Rio de Janeiro, Brazil). Meiofauna Marina, v.13, p. 37-44, 2004.
GERLACH, S. A. Freilebenden Nematoden Aus Der Lagoa Rodrigo De Freitas (Rio De Janeiro). Zoologischer Anz., v.153, p.135-143, 1954.

GERLACH, S. A. Brasilianische Meeresnematoden I. Bolm Inst. oceanogr., S. Paulo, v. 5, p. 3-69, 1956a.

GERLACH, S. A. Die Nematodenbeseiedlung des Tropischen Brandungsstrandes von Pernambuco, Brasilianische Meeres Nematoden II. Kieler Meeresforsch., v. 12, n. 2, p. 202-218, 1956b.

GERLACH, S. A. Marine Nematoden aus dem MangroveGebiet Voncananéia (Brasilianische Meeres-Nematoden Iii). Jb. Akad. der Wissenschaften Literatur Mainz, 5: 129-176, 1957a.

GERLACH, S. A. Die Nematodenfauna des Sandstrandes na der Küste von Mittelb (Brasilianische MeeresNematoden IV). Mitt. zool. Mus. Berl. , v. 33, n. 2, p. 411-459, 1957b.

GHEISKIERE, T.; HOSTE, E.; VANAVERBEKE, J.; VINCX, M.; DEGRAER, S. Horizontal zonation patterns and feeding structure of marine nematodes assemblages on a macortidal, ultra-dissipative sandy beach (De Panne, Belgium). J. Sea Res., v. 52, p. 211-226, 2004.

GHEISKIERE, T.; VINCX, M.; WESLAWSKI, J. M.; SCAPINI, F.; DEGRAER, S. Meiofauna as descriptor of tourism-induced changes at sandy-beaches. Mar. environ. Res., v. 60, p. 245-265, 2005.

GREISER, N.; FAUBEL. A. Biotic Factors. 79-114. In: HIGGINS, R. P.; THIEL, H. (Ed.). Introduction to the Study of Meiofauna. Washington, D.C.: Smithsonian Institution Press, 1988.

GUARINI, J. M.; BLANCHARD, G. F.; GROS, P.; HARRISON, S.J. Modelling the mud surface temperature on intertidal flats to investigate the spatiotemporal dynamics of the benthic microalgal photosynthetic capacity. Mar. Ecol. Progr. Ser., v. 153: 25-36, 1997.

HEIP, C.; VINCX, M.; VRANKEN, G. The ecology of marine nematodes. Oceanogr. mar. Biol. a. Rev., v. 23, p. 399-489, 1985.

HOPPER, B. E. Marine nematodes of Canada II. Marine nematodes from the MiBasin - Scots Bay of the Bay of Fundy, Nova Scotia. Can. J. Zool., v. 47, n. 4, p. 671690, 1969.

JAIRAJPURI, M. S. ;AHMAD, W. Dorylaimida. Freeliving, predaceous and plant-parasitic nematodes. New Delhi: Oxford \& IBH Publishing, 1992. MEDEIROS, L. R. DE A. Nematofauna de Praia Arenosa da Ilha Anchieta, São Paulo: 1. Estrutura trófica. In: SIMPÓSIO BRASILEIRO DE ECOSSISTEMAS, 4. Anais...v. 2, p. 166-178, 1998.

MOENS, T.; VINCX, M. Observations on the feeding ecology of estuarine nematodes. J. mar. Biol. Ass. U. K., v.77, p. 211-227, 1997.

MOSALIN, M. M.; MARINS, R. V.; MACHADO, W. ; PARAQUETTI, H.H. M. ; BIDONE, E. D.; LACERDA, L. D . Environmetal changes in Sepetiba Bay, SE Brazil. Regional environ. Change, 4, p. 17-27, 2004.

NETTO, S. A.; GALLUCCI, F. Meiofauna and macrofauna communities in a mangrove from the Island of Santa Catarina, South Brazil. Hydrobiologia, v. 505, p. 159170, 2003.

PARANHOS, R. Alguns métodos para a análise da água. Cadernos Didáticos, Rio de Janeiro, 19. 281 p. 1996. 
PLATT, H. M.; WARWICK, R. M. The significance of freeliving nematodes to the littoral ecosystem. Syst. Ass. Special, v. 17, p. 729-759, 1980.

PLATT, H. M.; WARWICK, R. M. Free-living marine nematodes. Part I: British Enoplids. Cambridge: Cambridge Univerty Press, 1983. 307 p.

POIMAN, G. The natural history of nematodes. Englewood Clipp: Practice-Hall Iniciation, 1983. 323 p.

RZEZNIK-ORIGNAC, J. ; FICHET, D.; BOUCHER, G Spatio-temporal structures of the nematode assemblages of the Brouage mudflat (Marennes Oléron, France). Estuar. coast. Shelf Sci., v. 58, p. 77-88, 2003.

SCHRATZBERGER, M.; GEE, J. M.; REES, H. L.; BOYD, S. E.; WALL, C. M. The structure and taxonomic composition of sublittoral meiofauna assemblages as an indicator of the status of marine environments. J. mar. biol. Ass. U.K., v. 80, p. 969 $980,2000$.

TIETJEN, J. E.; LEE, J. J. Life cycles of marine nematodes. Oecologia, v.10, p. 167-176, 1972.

VIGLIERCHO, D. R. The world of nematodes. Davis, CA: AgAcess, 1991. 266 p.
VENEKEY, V.; LAGE, L.M.; FONSÊCA-GENEVOIS, V. Draconema brasiliensis and Draconema fluminensis (Chromadorida, Draconematidae): two new species of free living nematodes from a rocky shore affected by upwelling on the Brazilian coast. Zootaxa, v. 1090, p. 51-64, 2005.

WARWICK, R. M.; PLATT, H. M.; SOMERFIELD, P. J. Free-living marine nematodes. Part 3. British Monhysterids. London: The Linnean Society of London and the Estuarine and Coastal Sciences Association, 1998. 296 p.

WIESER, W. Die Beziehung zwischen Mundhöhlengestalt, Ernährungsweise und Vorkommen beifrelebenden marinen nematoden. Archs Zool., v. 4 , n. 26, p. 439484, 1953.

ZAR, J. H. Biostatistical analysis. New Jersey: PrenticeHall, 1996. 662 p.

(Manuscript received 09 June 2006; revised 16 April 2007; accepted 02 August 2007) 